Supplement of Biogeosciences, 17, 3961-3989, 2020 https://doi.org/10.5194/bg-17-3961-2020-supplement (C) Author(s) 2020. This work is distributed under the Creative Commons Attribution 4.0 License.

(c) (1)

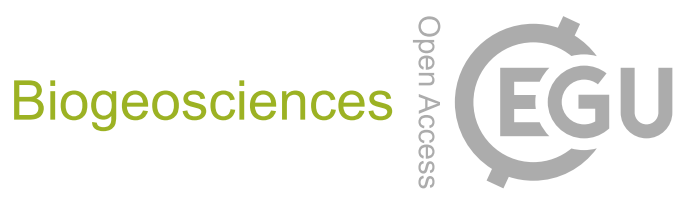

Supplement of

\title{
Understanding the uncertainty in global forest carbon turnover
}

Thomas A. M. Pugh et al.

Correspondence to: Thomas A. M. Pugh (t.a.m.pugh@bham.ac.uk)

The copyright of individual parts of the supplement might differ from the CC BY 4.0 License. 
Table S1. Plant functional types (PFTs) simulated by each terrestrial biosphere model (TBM) and their grouping into forest-type classifications.

\begin{tabular}{|c|c|c|c|c|c|c|}
\hline \multirow{2}{*}{$\begin{array}{l}\text { Forest-type } \\
\text { classifications }\end{array}$} & \multicolumn{6}{|c|}{ TBM PFTs (forest-type classification in parentheses) } \\
\hline & CABLE-POP & JULES & LPJ-GUESS & LPJmL & ORCHIDEE & SEIB-DGVM \\
\hline $\begin{array}{l}\text { Tropical broadleaved } \\
\text { deciduous (TrBD) }\end{array}$ & $\begin{array}{l}\text { Deciduous broadleaf } \\
\text { forest }(\operatorname{TrBD}, \mathrm{TeBD}, \\
\left.\qquad \mathrm{BBD}^{\mathrm{a}}\right)\end{array}$ & $\begin{array}{l}\text { Broadleaf deciduous tree } \\
\left(\mathrm{TrBD}, \mathrm{TeBD}, \mathrm{BBD}^{\mathrm{a}}\right)\end{array}$ & $\begin{array}{l}\text { Tropical broadleaf } \\
\text { raingreen tree }(\operatorname{TrBD})\end{array}$ & $\begin{array}{l}\text { Tropical broad-leaved } \\
\text { raingreen tree }(\mathrm{TrBD})\end{array}$ & $\begin{array}{l}\text { Tropical broad-leaved } \\
\text { raingreen tree }(\mathrm{TrBD})\end{array}$ & $\begin{array}{l}\text { Tropical broad-leaved } \\
\text { raingreen tree }(\mathrm{TrBD})\end{array}$ \\
\hline $\begin{array}{l}\text { Tropical broadleaved } \\
\text { evergreen }(\mathrm{TrBE})\end{array}$ & $\begin{array}{l}\text { Evergreen broadleaf } \\
\text { forest }(\mathrm{TrBE}, \mathrm{TeBE})\end{array}$ & $\begin{array}{l}\text { Tropical broadleaved } \\
\text { evergreen tree (TrBE) }\end{array}$ & $\begin{array}{c}\text { Tropical broadleaf } \\
\text { evergreen tree }(\operatorname{TrBE})^{\mathrm{b}}\end{array}$ & $\begin{array}{l}\text { Tropical broad-leaved } \\
\text { evergreen tree (TrBE) }\end{array}$ & $\begin{array}{l}\text { Tropical broad-leaved } \\
\text { evergreen tree (TrBE) }\end{array}$ & $\begin{array}{l}\text { Tropical broad-leaved } \\
\text { evergreen tree (TrBE) }\end{array}$ \\
\hline $\begin{array}{c}\text { Temperate } \\
\text { broadleaved } \\
\text { deciduous (TeBD) }\end{array}$ & $\begin{array}{l}\text { Deciduous broadleaf } \\
\text { forest }(\operatorname{TrBD}, \text { TeBD, } \\
\left.\qquad \mathrm{BBD}^{\mathrm{a}}\right)\end{array}$ & $\begin{array}{l}\text { Broadleaf deciduous tree } \\
\left(\mathrm{TrBD}, \mathrm{TeBD}, \mathrm{BBD}^{\mathrm{a}}\right)\end{array}$ & $\begin{array}{c}\text { Temperate broadleaf } \\
\text { summergreen tree (TeBD, } \\
\text { BBD })^{\mathrm{b}}\end{array}$ & $\begin{array}{c}\text { Temperate broad-leaved } \\
\text { summergreen tree }(\mathrm{TeBD})\end{array}$ & $\begin{array}{c}\text { Temperate broad-leaved } \\
\text { summergreen tree } \\
(\mathrm{TeBD})\end{array}$ & $\begin{array}{c}\text { Temperate broad-leaved } \\
\text { summergreen tree (TeBD) }\end{array}$ \\
\hline $\begin{array}{c}\text { Temperate } \\
\text { broadleaved evergreen } \\
(\mathrm{TeBE})\end{array}$ & $\begin{array}{l}\text { Evergreen broadleaf } \\
\text { forest }(\mathrm{TrBE}, \mathrm{TeBE})\end{array}$ & $\begin{array}{l}\text { Temperate broadleaved } \\
\text { evergreen tree (TeBE) }\end{array}$ & $\begin{array}{c}\text { Temperate broadleaf } \\
\text { evergreen tree }(\mathrm{TeBE})\end{array}$ & $\begin{array}{l}\text { Temperate broad-leaved } \\
\text { evergreen tree (TeBE) }\end{array}$ & $\begin{array}{l}\text { Temperate broad-leaved } \\
\text { evergreen tree (TeBE) }\end{array}$ & $\begin{array}{l}\text { Temperate broad-leaved } \\
\text { evergreen tree }(\mathrm{TeBE})\end{array}$ \\
\hline $\begin{array}{l}\text { Boreal broadleaved } \\
\text { deciduous (BBD) }\end{array}$ & $\begin{array}{l}\text { Deciduous broadleaf } \\
\text { forest }(\operatorname{TrBD}, \text { TeBD, } \\
\left.\qquad \mathrm{BBD}^{\mathrm{a}}\right)\end{array}$ & $\begin{array}{l}\text { Broadleaf deciduous tree } \\
\left(\mathrm{TrBD}, \mathrm{TeBD}, \mathrm{BBD}^{\mathrm{a}}\right)\end{array}$ & $\mathrm{NA}^{\mathrm{c}}$ & $\begin{array}{c}\text { Boreal broad-leaved } \\
\text { summergreen tree (BBD) }\end{array}$ & $\begin{array}{c}\text { Boreal broad-leaved } \\
\text { summergreen tree (BBD) }\end{array}$ & $\begin{array}{c}\text { Boreal broad-leaved } \\
\text { summergreen tree (BBD) }\end{array}$ \\
\hline $\begin{array}{c}\text { Needleleaved } \\
\text { deciduous (ND) }\end{array}$ & $\begin{array}{l}\text { Deciduous needleleaf } \\
\text { forest (ND) }\end{array}$ & $\begin{array}{l}\text { Needleleaf deciduous tree } \\
\text { (ND) }\end{array}$ & $\begin{array}{c}\text { Boreal needleleaf } \\
\text { summergreen tree (ND) }\end{array}$ & $\mathrm{NA}^{\mathrm{c}}$ & $\begin{array}{c}\text { Boreal needleleaf } \\
\text { summergreen tree (ND) }\end{array}$ & $\begin{array}{c}\text { Boreal needle-leaved } \\
\text { summergreen tree (ND) }\end{array}$ \\
\hline $\begin{array}{c}\text { Needleleaved } \\
\text { evergreen (NE) }\end{array}$ & $\begin{array}{l}\text { Evergreen needleleaf } \\
\quad \text { forest }(\mathrm{NE})\end{array}$ & $\begin{array}{c}\text { Needleleaf evergreen tree } \\
\text { (NE) }\end{array}$ & $\begin{array}{c}\text { Boreal needleleaf } \\
\text { evergreen tree }(\mathrm{NE})^{\mathrm{b}}\end{array}$ & $\begin{array}{c}\text { Temperate needle-leaved } \\
\text { evergreen tree (NE) } \\
\text { Boreal needle-leaved } \\
\text { evergreen tree (NE) }\end{array}$ & $\begin{array}{l}\text { Temperate needleleaf } \\
\text { evergreen tree (NE) } \\
\text { Boreal needleleaf } \\
\text { evergreeen tree (NE) }\end{array}$ & $\begin{array}{c}\text { Temperate needle-leaved } \\
\text { evergreen tree (NE) } \\
\text { Boreal needle-leaved } \\
\text { evergreen tree (NE) }\end{array}$ \\
\hline $\begin{array}{l}\text { Non-forest (NF), } \\
\text { shrub }\end{array}$ & Shrub (NF) & $\begin{array}{l}\text { Deciduous shrub (NF) } \\
\text { Evergreen shrub (NF) }\end{array}$ & $\mathrm{NA}^{\mathrm{c}}$ & $\mathrm{NA}^{\mathrm{c}}$ & $\mathrm{NA}^{\mathrm{c}}$ & $\mathrm{NA}^{\mathrm{c}}$ \\
\hline $\begin{array}{l}\text { Non-forest (NF), } \\
\text { herbaceous }\end{array}$ & $\begin{array}{l}\mathrm{C} 3 \text { grass }(\mathrm{NF}) \\
\mathrm{C} 4 \text { grass }(\mathrm{NF})\end{array}$ & $\begin{array}{l}\text { C3 grass (NF) } \\
\text { C4 grass (NF) }\end{array}$ & $\begin{array}{l}\mathrm{C} 3 \text { grasses }(\mathrm{NF}) \\
\mathrm{C} 4 \text { grasses }(\mathrm{NF})\end{array}$ & $\begin{array}{l}\text { Tropical herbaceous (NF) } \\
\text { Temperate herbaceous (NF) }\end{array}$ & $\begin{array}{l}\mathrm{C} 3 \text { grass }(\mathrm{NF}) \\
\mathrm{C} 4 \text { grass }(\mathrm{NF})\end{array}$ & $\begin{array}{l}\text { Tropical herbaceous (NF) } \\
\text { Temperate herbaceous (NF) }\end{array}$ \\
\hline
\end{tabular}

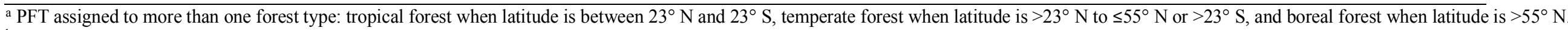

${ }^{\mathrm{b}}$ Both shade-tolerant and shade intolerant PFTs simulated.

${ }^{c}$ PFT not simulated for this study. 
Table S2. Phenological longevity parameters (years) in the terrestrial biosphere model (TBM) ensemble.

\begin{tabular}{|c|c|c|c|c|c|c|c|c|c|c|c|c|}
\hline \multirow[t]{3}{*}{ Forest type $^{c}$} & \multicolumn{12}{|c|}{ Model } \\
\hline & \multicolumn{2}{|c|}{ CABLE-POP } & \multicolumn{2}{|c|}{ JULES } & \multicolumn{2}{|c|}{ LPJ-GUESS } & \multicolumn{2}{|c|}{ LPJmL } & \multicolumn{2}{|c|}{ ORCHIDEE } & \multicolumn{2}{|c|}{ SEIB-DGVM } \\
\hline & Leaf & $\operatorname{Root}^{d}$ & Leaf & $\operatorname{Root}^{d}$ & Leaf & $\operatorname{Root}^{\mathrm{d}}$ & Leaf & $\operatorname{Root}^{d}$ & Leaf & $\operatorname{Root}^{d}$ & Leaf & $\operatorname{Root}^{d}$ \\
\hline $\begin{array}{l}\text { Boreal needleleaved } \\
\text { deciduous }\end{array}$ & 0.52 & 0.7 & $1.0^{\mathrm{a}}$ & 6.67 & $1.0^{\mathrm{b}}$ & 1.4 & 1.0 & 1.0 & $1.0^{\mathrm{b}}$ & $1.0^{\mathrm{b}}$ & $1.0^{\mathrm{b}}$ & 5.0 \\
\hline $\begin{array}{l}\text { Boreal needleleaved } \\
\text { evergreen }\end{array}$ & 3.5 & 0.7 & $4.0^{\mathrm{a}}$ & 6.67 & 3.0 & 1.4 & 2.0 & 2.0 & 3.0 & 3.0 & 4.55 & 2.38 \\
\hline $\begin{array}{c}\text { Boreal broadleaved } \\
\text { deciduous }\end{array}$ & $\mathrm{n} / \mathrm{a}$ & $\mathrm{n} / \mathrm{a}$ & $\mathrm{n} / \mathrm{a}$ & $\mathrm{n} / \mathrm{a}$ & $\mathrm{n} / \mathrm{a}$ & $\mathrm{n} / \mathrm{a}$ & 1.0 & 1.0 & $1.0^{\mathrm{b}}$ & $1.0^{\mathrm{b}}$ & $1.0^{\mathrm{b}}$ & 2.13 \\
\hline $\begin{array}{c}\text { Temperate needleleaved } \\
\text { evergreen }\end{array}$ & 3.5 & 0.7 & $\mathrm{n} / \mathrm{a}$ & $\mathrm{n} / \mathrm{a}$ & $\mathrm{n} / \mathrm{a}$ & $\mathrm{n} / \mathrm{a}$ & 2.0 & 2.0 & 3.0 & 3.0 & 4.55 & 1.56 \\
\hline $\begin{array}{c}\text { Temperate broadleaved } \\
\text { evergreen }\end{array}$ & 3.5 & 0.7 & $2.0^{\mathrm{a}}$ & 4.0 & 3.0 & 1.4 & 1.0 & 1.0 & 1.0 & 1.0 & 2.63 & 1.56 \\
\hline $\begin{array}{l}\text { Temperate broadleaved } \\
\text { deciduous }\end{array}$ & 2 & 0.7 & $1.0^{\mathrm{a}}$ & 4.0 & $1.0^{\mathrm{b}}$ & 1.4 & 1.0 & 1.0 & $1.0^{\mathrm{b}}$ & $1.0^{\mathrm{b}}$ & $1.0^{\mathrm{b}}$ & 1.56 \\
\hline $\begin{array}{c}\text { Tropical broadleaved } \\
\text { evergreen }\end{array}$ & 3.5 & 0.7 & $4.0^{\mathrm{a}}$ & 4.0 & 2.0 & 1.4 & 2.0 & 2.0 & 2.5 & 2.5 & 1.69 & 1.32 \\
\hline $\begin{array}{c}\text { Tropical broadleaved } \\
\text { deciduous }\end{array}$ & $\mathrm{n} / \mathrm{a}$ & $\mathrm{n} / \mathrm{a}$ & $1.0^{\mathrm{a}}$ & 4.0 & $1.0^{\mathrm{b}}$ & 1.4 & 1.0 & 1.0 & $1.0^{\mathrm{b}}$ & $1.0^{\mathrm{b}}$ & $1.0^{\mathrm{b}}$ & 0.63 \\
\hline C3 herb & 0.5 & 0.29 & 0.33 & 4.0 & 1.0 & 1.4 & 1.0 & 2.0 & 0.5 & 0.5 & 2.0 & 2.50 \\
\hline C4 herb & 0.5 & 0.21 & 0.33 & 4.0 & 1.0 & 1.4 & 1.0 & 2.0 & 0.5 & 0.5 & 2.0 & 1.3 \\
\hline
\end{tabular}

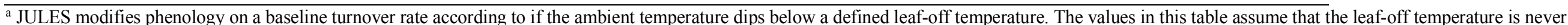
achieved for evergreen trees, but is achieved every year for deciduous trees.

${ }^{\mathrm{b}}$ Reported here as one for deciduous phenologies on the assumption that only one leaf flush per year will be permitted. Actual leaf longevity is shorter.

${ }^{c}$ Where forest-type classifications cover multiple PFTs, the most representative PFT is listed.

${ }^{\mathrm{d}}$ All root values are reported for fine roots only. 
Table S3. Mapping of European Space Agency (ESA) landcover classes to forest types used in this analysis.

\begin{tabular}{|c|c|c|c|}
\hline Code & Forest-type classification & $\begin{array}{c}\text { ESA landcover } \\
\text { classes }^{1}\end{array}$ & Additional conditions \\
\hline TrBE & Tropical broadleaved evergreen & 50 & latitude $\leq 23^{\circ}$ \\
\hline $\operatorname{TrBD}$ & Tropical broadleaved deciduous & $60,61,62$ & latitude $\leq 23^{\circ}$ \\
\hline $\mathrm{OTr}$ & Other tropical forest & $100,160,170$ & latitude $\leq 23^{\circ}$ \\
\hline TeBE & Temperate broadleaved evergreen & 50 & latitude $>23^{\circ}$ \\
\hline TeBD & Temperate broadleaved deciduous & $60,61,62$ & latitude $>23^{\circ}$ \\
\hline NE & Needleleaved evergreen & $70,71,72$ & $\mathrm{n} / \mathrm{a}$ \\
\hline ND & Needleleaved deciduous & $80,81,82$ & $\mathrm{n} / \mathrm{a}$ \\
\hline MX & Broadleaved-needleleaved mixed forest & 90 & $\mathrm{n} / \mathrm{a}$ \\
\hline Other & Other forest & $100,160,170$ & latitude $>23^{\circ}$ \\
\hline
\end{tabular}

${ }^{1}$ ESA (2017), Pugh et al. (2019b) 
Table S4. Leaf area to sapwood area ratios used in the terrestrial biosphere model (TBM) ensemble

\begin{tabular}{|c|c|c|c|c|c|c|}
\hline \multirow[t]{2}{*}{ PFT type $^{\mathrm{a}}$} & \multicolumn{6}{|c|}{ LA:SA $\left(\mathrm{m}^{2} \mathrm{~cm}^{-2}\right)$} \\
\hline & CABLE-POP & JULES & LPJ-GUESS & LPJmL & ORCHIDEE & SEIB-DGVM \\
\hline Boreal needleleaved deciduous & 4000 & $\mathrm{~b}$ & 5000 & 8000 & no constraint & 6000 \\
\hline Boreal needleleaved evergreen & 4000 & $\mathrm{~b}$ & 5000 & 8000 & no constraint & 6000 \\
\hline Boreal broadleaved deciduous & 4000 & $\mathrm{n} / \mathrm{a}$ & $\mathrm{n} / \mathrm{a}$ & $\mathrm{n} / \mathrm{a}$ & $\mathrm{n} / \mathrm{a}$ & 8500 \\
\hline Temperate needleleaved evergreen & 4000 & $\mathrm{n} / \mathrm{a}$ & $\mathrm{n} / \mathrm{a}$ & 8000 & no constraint & 4800 \\
\hline Temperate broadleaved evergreen & 4000 & $\mathrm{~b}$ & 6000 & 8000 & no constraint & 4800 \\
\hline Temperate broadleaved deciduous & 4000 & $\mathrm{~b}$ & 6000 & 8000 & no constraint & 14500 \\
\hline Tropical broadleaved evergreen & 4000 & $\mathrm{~b}$ & 6000 & 8000 & no constraint & no constraint \\
\hline Tropical broadleaved deciduous & 4000 & $\mathrm{~b}$ & 6000 & 8000 & no constraint & no constraint \\
\hline
\end{tabular}

${ }^{a}$ Where forest-type classifications cover multiple PFTs, the value for the most representative PFT is listed.

b JULES does not define an area ratio, but instead relates leaf area to mass of sapwood for the purpose of calculating respiration (Eq. 46 in Clark et al., 2011 ). 
Table S5. Performance of terrestrial biosphere models (TBMs) in capturing observed drought-induced mortality events.

\begin{tabular}{|c|c|c|c|c|c|c|}
\hline \multirow[t]{3}{*}{ Model } & \multirow[t]{3}{*}{$\mathbf{N}^{1}$} & \multicolumn{5}{|c|}{ Fraction of observed drought-induced events with increased mortality } \\
\hline & & \multicolumn{2}{|c|}{ All mechanisms } & \multicolumn{3}{|c|}{ Most drought-sensitive relevant process } \\
\hline & & $\begin{array}{c}\text { Drought } \\
\text { period }+5 \\
\text { years }\end{array}$ & Random $^{2}$ & $\begin{array}{c}\text { Drought } \\
\text { period + } 5 \\
\text { years }\end{array}$ & Random & $\begin{array}{c}\text { Process-type } \\
\text { (Table 3) }\end{array}$ \\
\hline $\begin{array}{c}\text { CABLE- } \\
\text { POP }\end{array}$ & 25 & 0.08 & 0.03 & 0.12 & 0.02 & Growth efficiency \\
\hline JULES & 25 & 0.16 & 0.04 & 0.16 & 0.12 & Self-thinning \\
\hline LPJ-GUESS & 26 & 0.04 & 0.02 & 0.12 & 0.04 & Growth efficiency \\
\hline LPJmL & 19 & 0.11 & 0.05 & 0.11 & 0.03 & Self-thinning \\
\hline ORCHIDEE & 22 & 0.05 & 0.04 & $\mathrm{n} / \mathrm{a}$ & $\mathrm{n} / \mathrm{a}$ & $\mathrm{n} / \mathrm{a}$ \\
\hline $\begin{array}{l}\text { SEIB- } \\
\text { DGVM }\end{array}$ & 25 & 0.04 & 0.04 & 0.27 & 0.04 & Bioclimatic limits \\
\hline
\end{tabular}

${ }^{1}$ Total number of events for which the model simulated forest and a mortality flux was recorded in at least one year during the period 1901-2015.

${ }^{2}$ Mean of 10 randomly selected year ranges. 

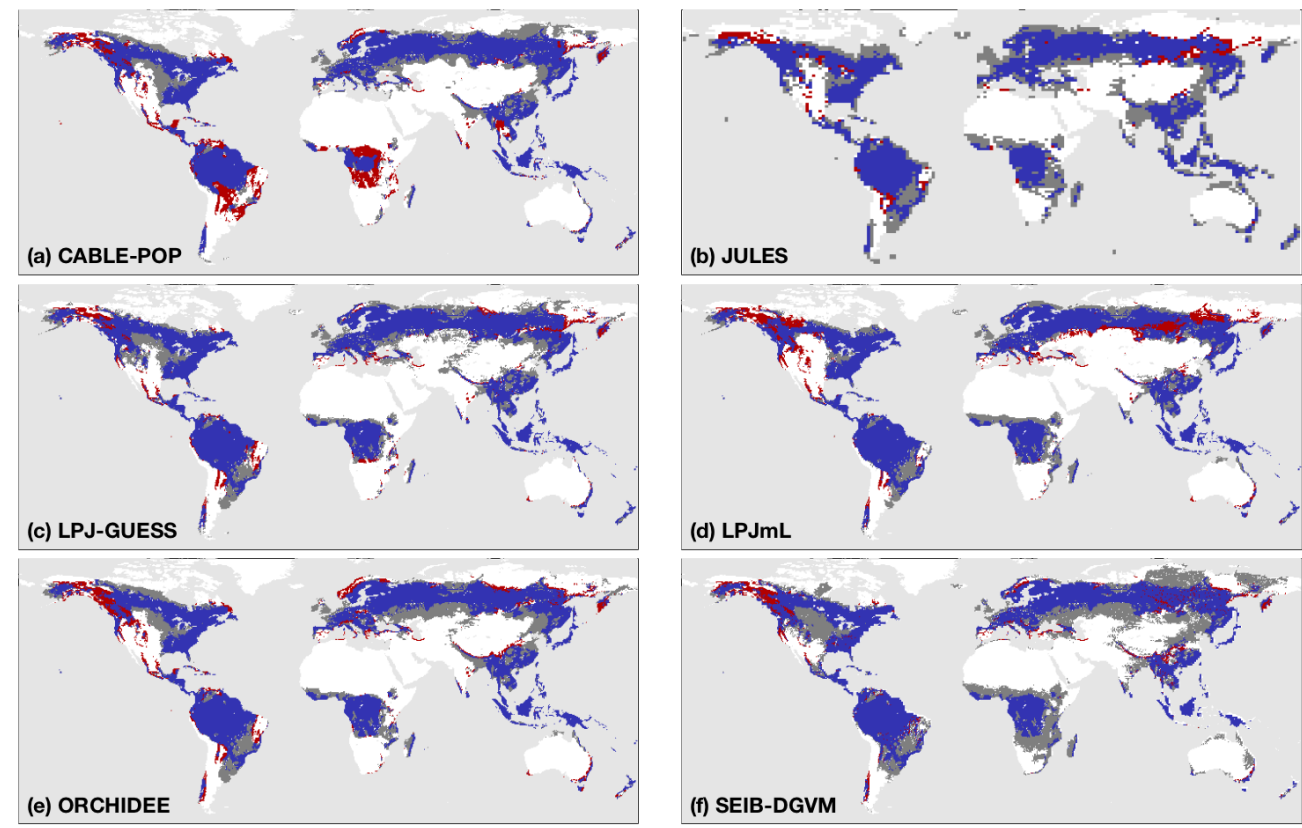

Figure S1. Evaluation of grid-cells where TBMs simulate forest for the period 1985-2014 (see Methods for definition) against satellite observations for the year 2000 (Hansen et al., 2013). Blue shading indicates where the TBM simulates forest and satellite observations find at least $10 \%$ of the grid-cell to be covered by forest with a 50\% canopy-cover threshold (Pugh et al., 2019a). Red shading indicates where forest is observed in the satellite data but not simulated by the TBM. Grey shading indicates where forest is simulated by the TBM but is not observed in the satellite data. 


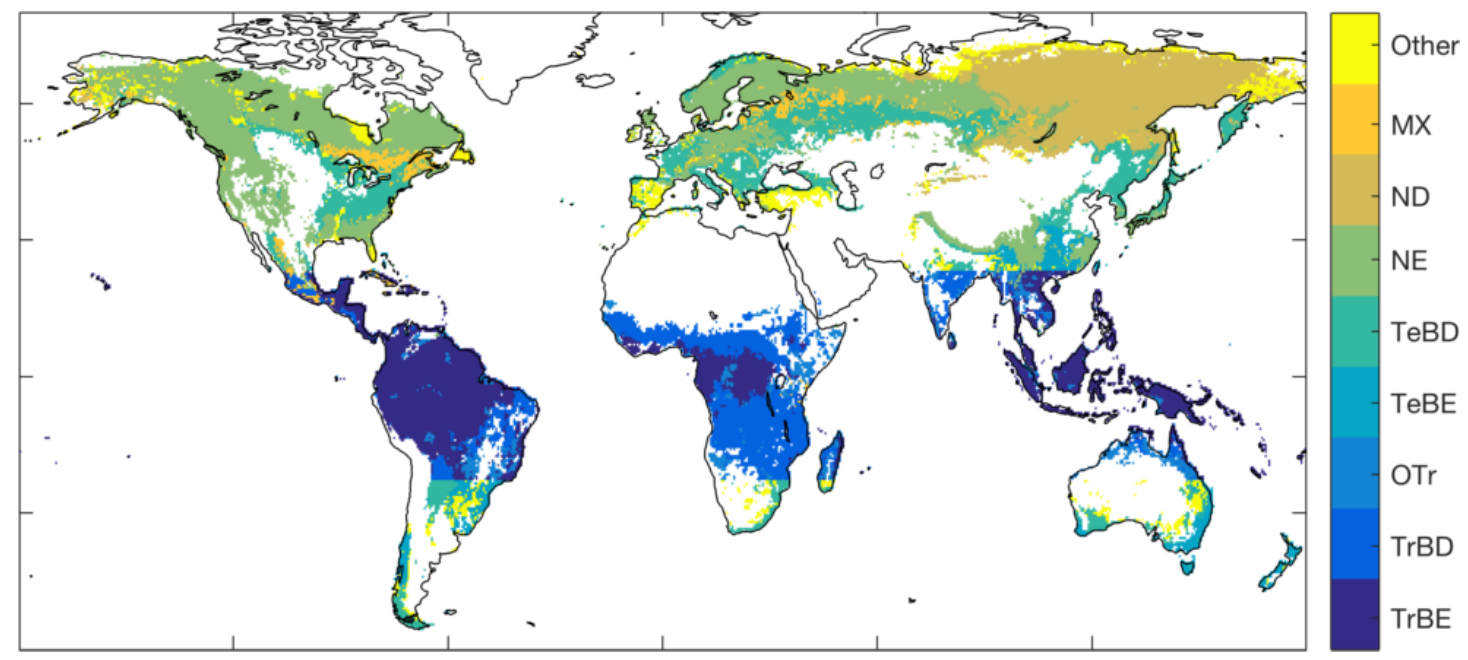

Figure S2. Forest type regions based on the European Space Agency (ESA) land-cover map (ESA 2017). Reproduced from Pugh et al. (2019b), Fig. S9. See Table S3 for forest type codes. 

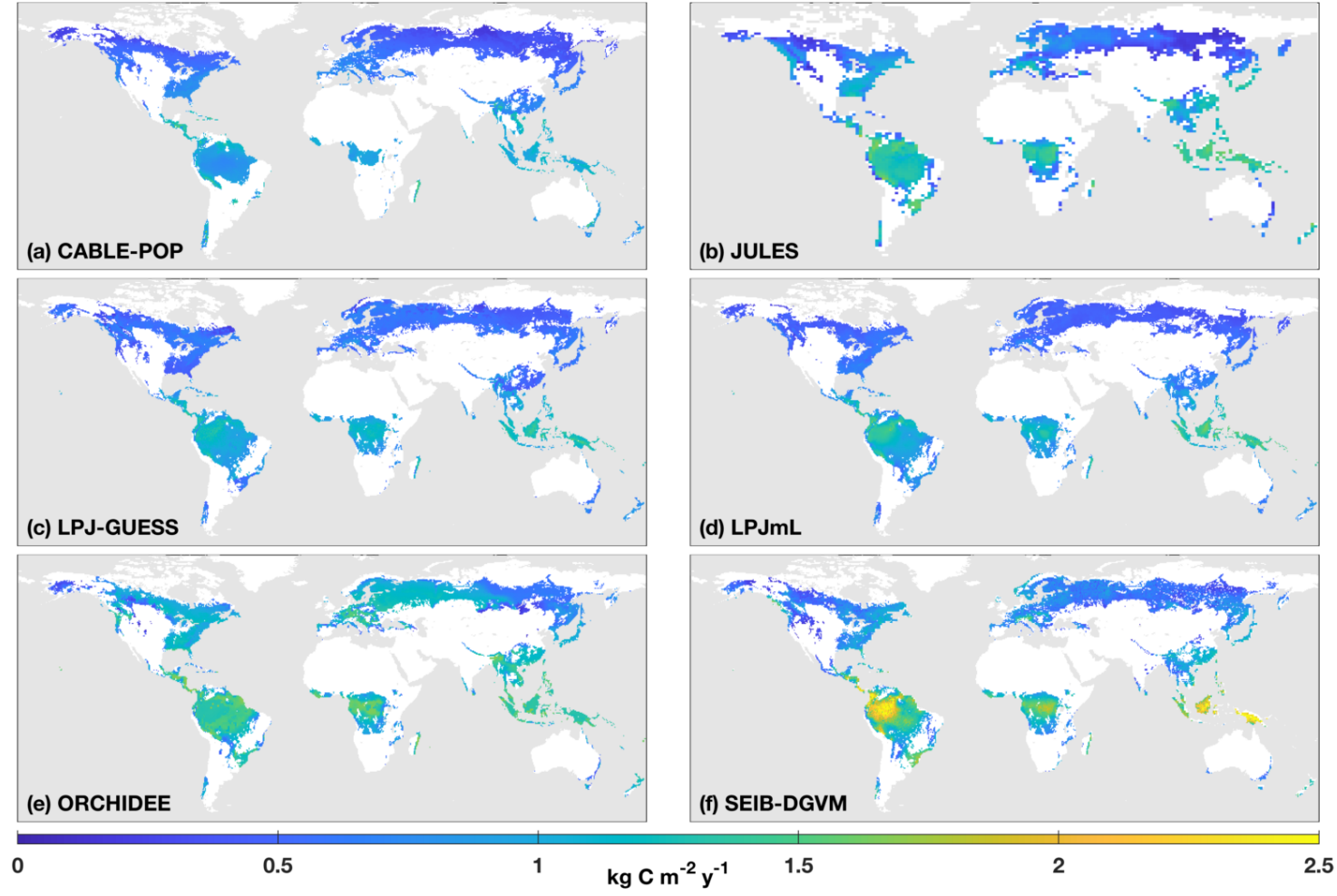

Figure S3. NPP mean for the period 1985-2014 as forced by the CRU-NCEP climate (units of $\mathrm{kg} \mathrm{C}^{-2} \mathrm{y}^{-1}$ ). Colour scale is capped at $2.5 \mathrm{~kg} \mathrm{C} \mathrm{m}^{-2} \mathrm{y}^{-1}$. Maps show areas which are simulated as forest for each model and have at least $10 \%$ of the grid-cell covered by closed-canopy forest (see Methods). 


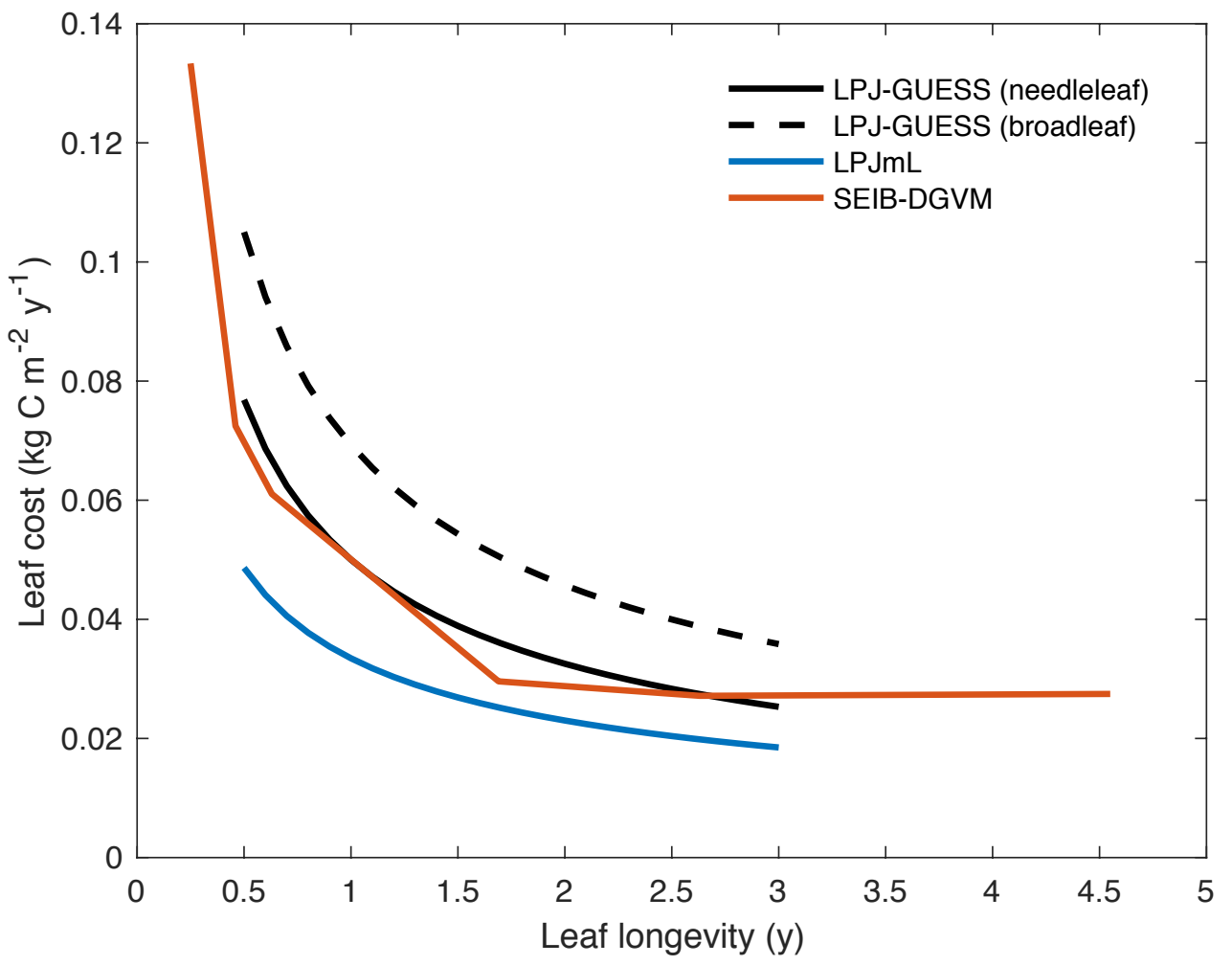

Figure S4. Leaf $C$ cost as a function of longevity for three of the TBMs. Leaf $C$ cost is defined as the reciprocal of specific leaf area divided by leaf longevity. 

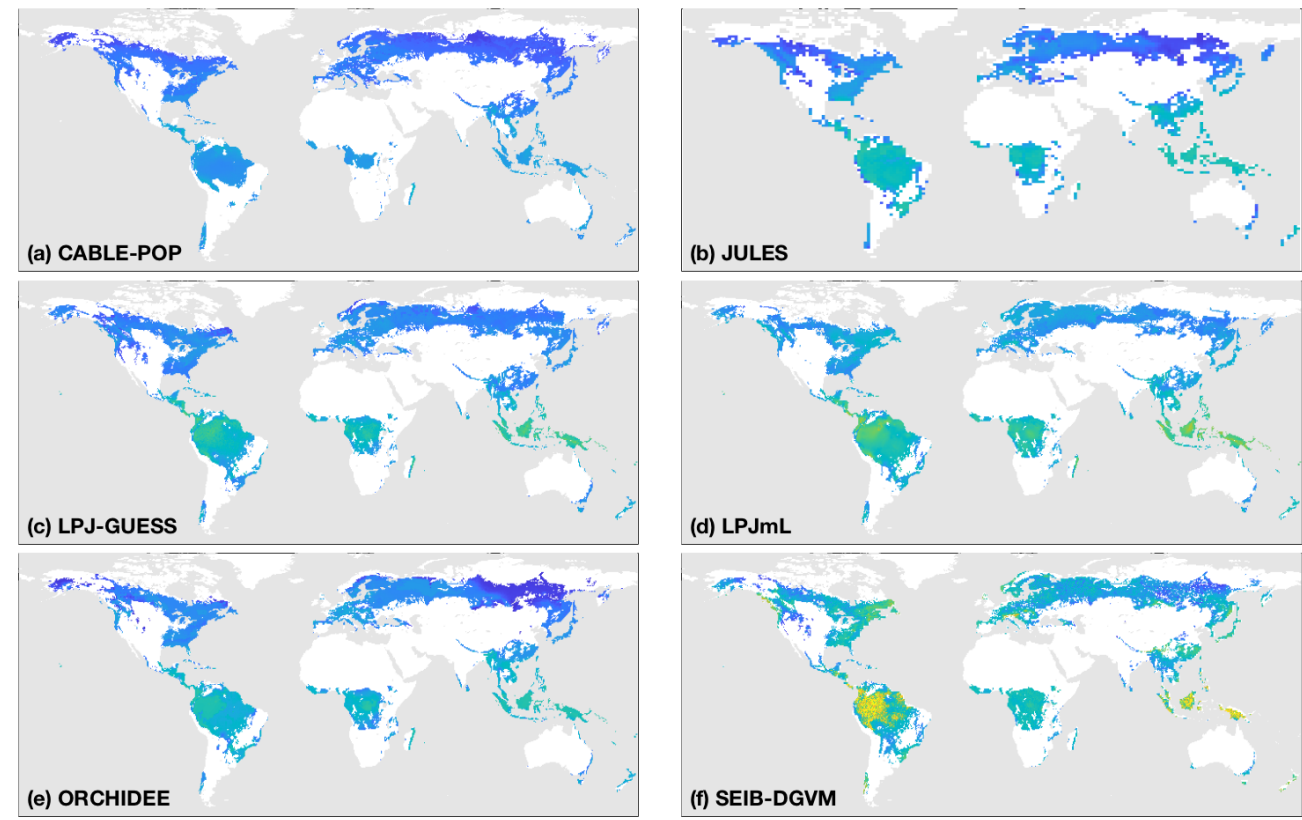

(e) ORCHIDEE

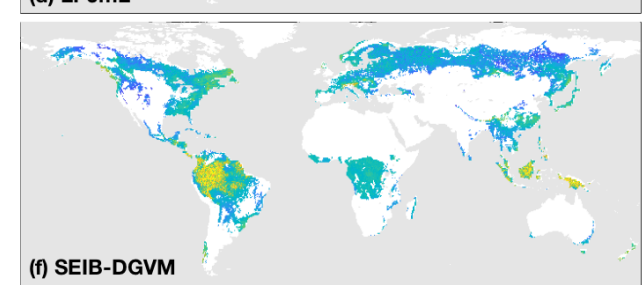

2

4

Figure S5. Annual mean maximum value of the monthly LAI $\left(\mathrm{m}^{2} \mathrm{~m}^{-2}\right)$ over the period 1985-2014 in the CRU-NCEP-forced simulation. 

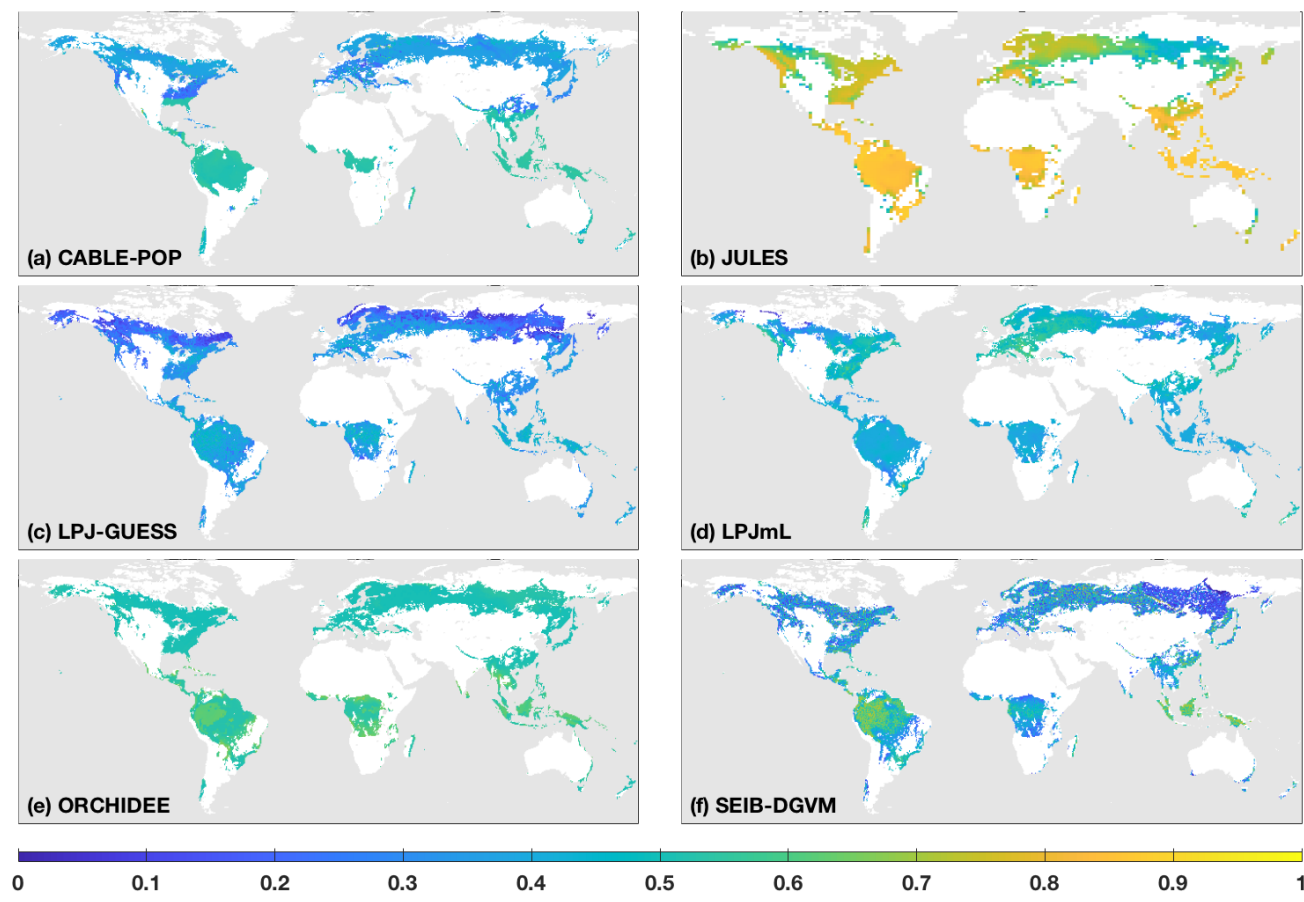

Figure S6. Fraction of $F_{\text {turn }}$ which results from mortality $\left(F_{\text {mort }} / F_{\text {turn }}\right)$, for the period 1985-2014 as forced by the CRU-NCEP climate. The fraction of $F_{\text {turn }}$ resulting from phenological processes is the remainder. Masking as for Fig. 1. 

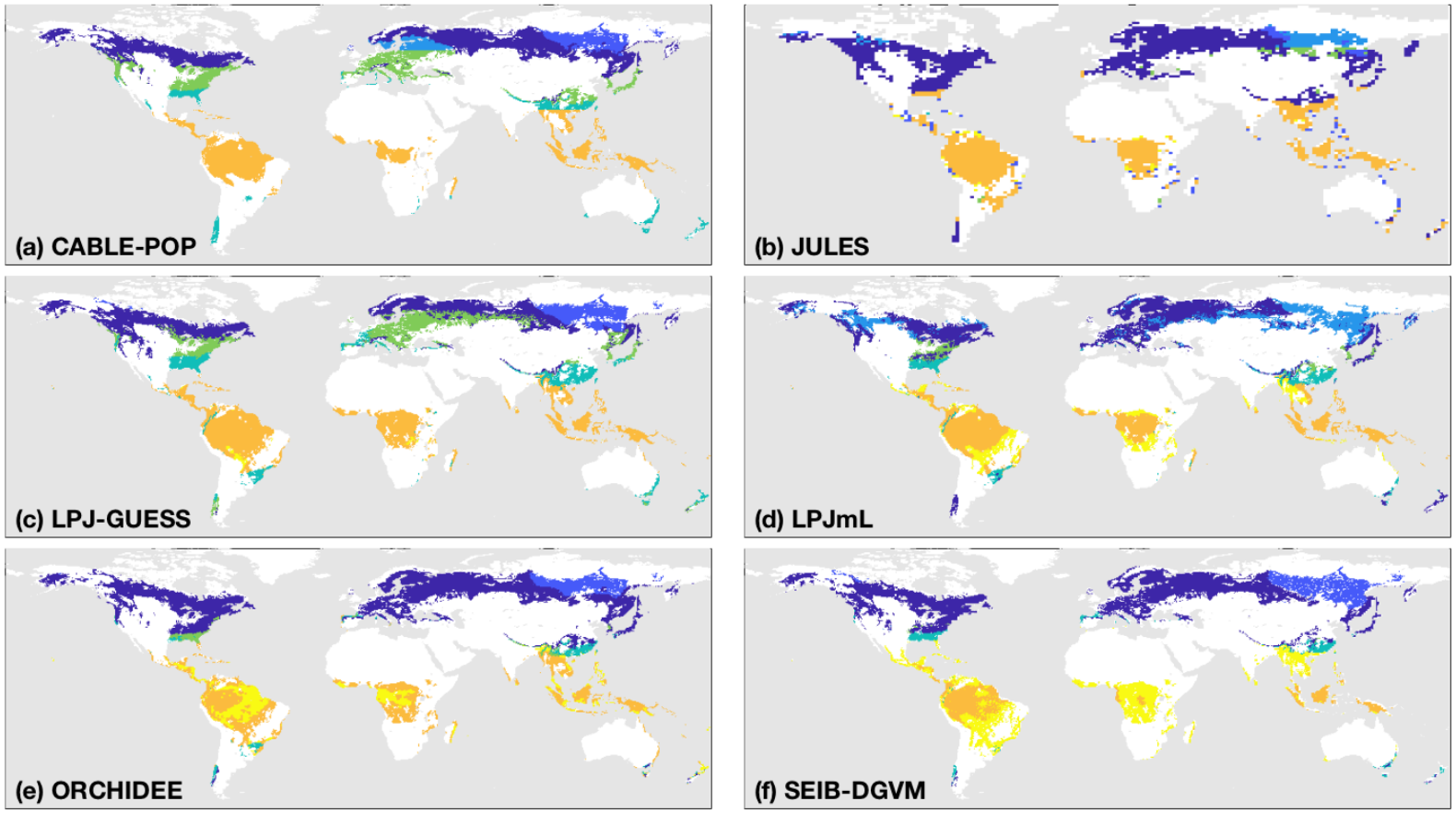

tropical broadleaved deciduous tropical broadleaved evergreen temperate broadleaved deciduous temperate broadleaved evergreen boreal broadleaved deciduous needleleaved deciduous needleleaved evergreen

Figure S7. Distribution of the model simulated forest types during 1985-2014 based on the CRU-NCEP simulation. 


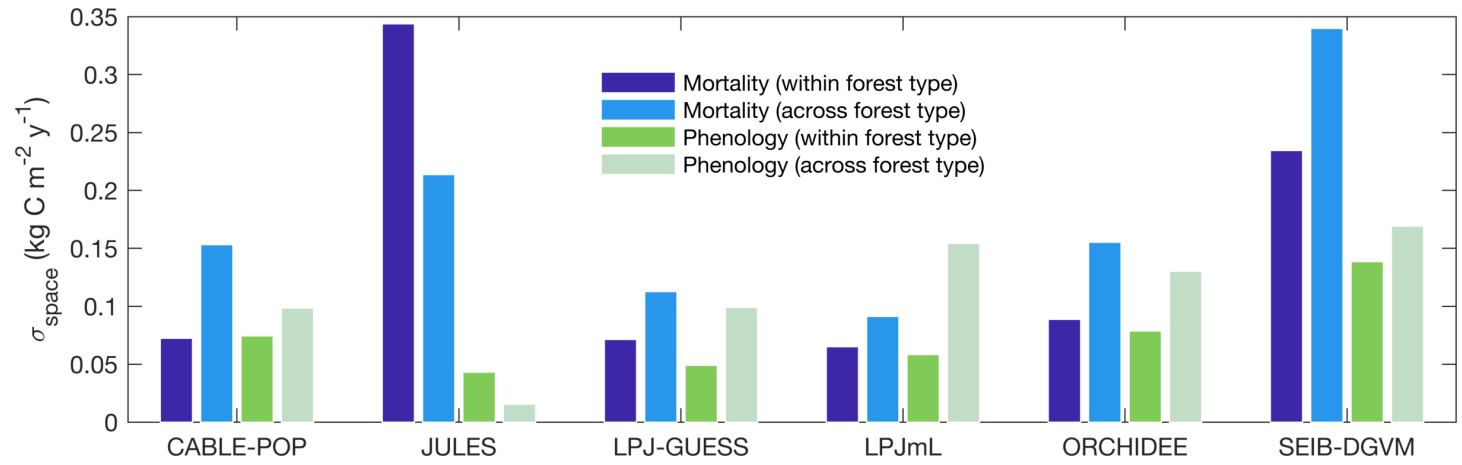

Figure S8. Standard deviation of turnover fluxes in space for $F_{\text {mort }}$ and $F_{\text {phen }}$, calculated by model forest types over the period 19852014 from the CRU-NCEP-forced simulation. For "within forest type" variance was calculated for each forest type, before taking the square root of the mean variance across all forest types. For "across forest type" the mean of fluxes across each forest type was taken, before calculating the standard deviation of these forest-type means. Calculations were only made across grid-cells with at least $10 \%$ forest cover. Comparisons of absolute numbers from JULES with those of other TBMs should be avoided because of the different spatial resolution. 


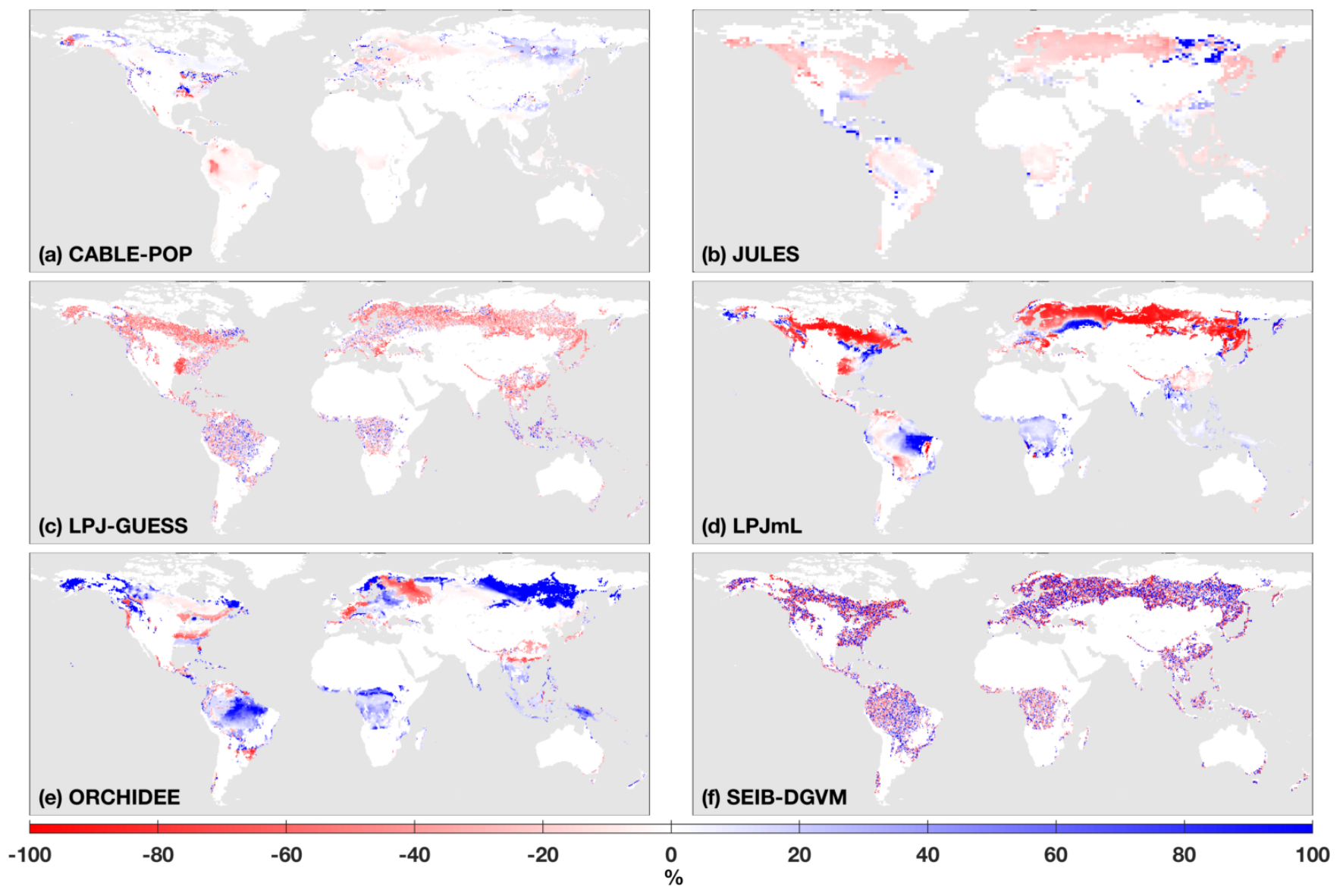

Figure S9. Percentage change in $\tau_{\text {mort }}\left(C_{v e g} / F_{\text {mort }}\right)$ mean between the periods 1985-2014 and 2070-2099 as forced by the IPSL-CM5ALR climate (units of years). Masking as for Fig. 1. 

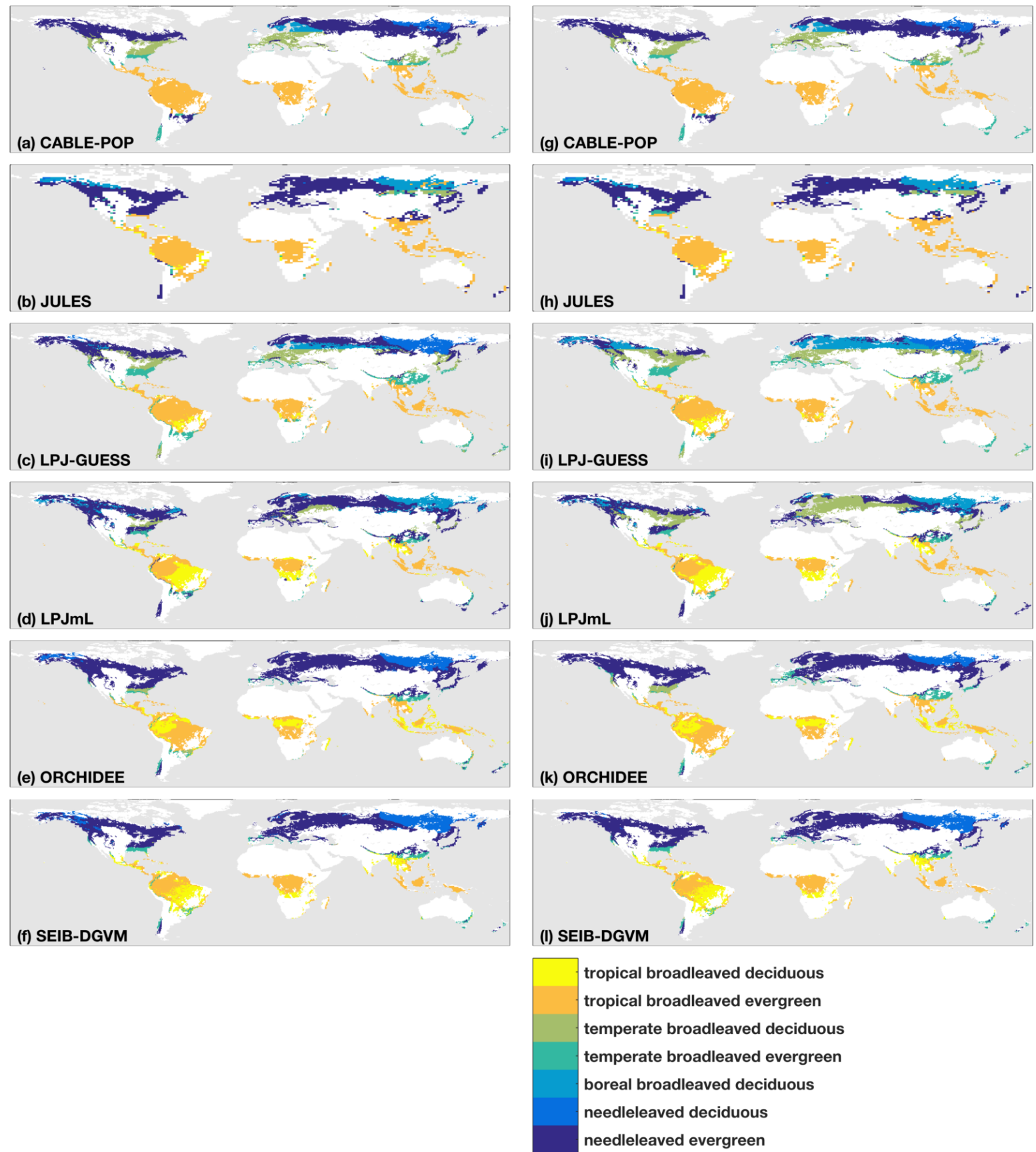

Figure S10. Distribution of the model simulated forest types during 1985-2014 (a-f) and 2070-2099 (g-l) in the TBM simulations forced by IPSL-CM5A-LR RCP 8.5 bias-corrected climate data. 

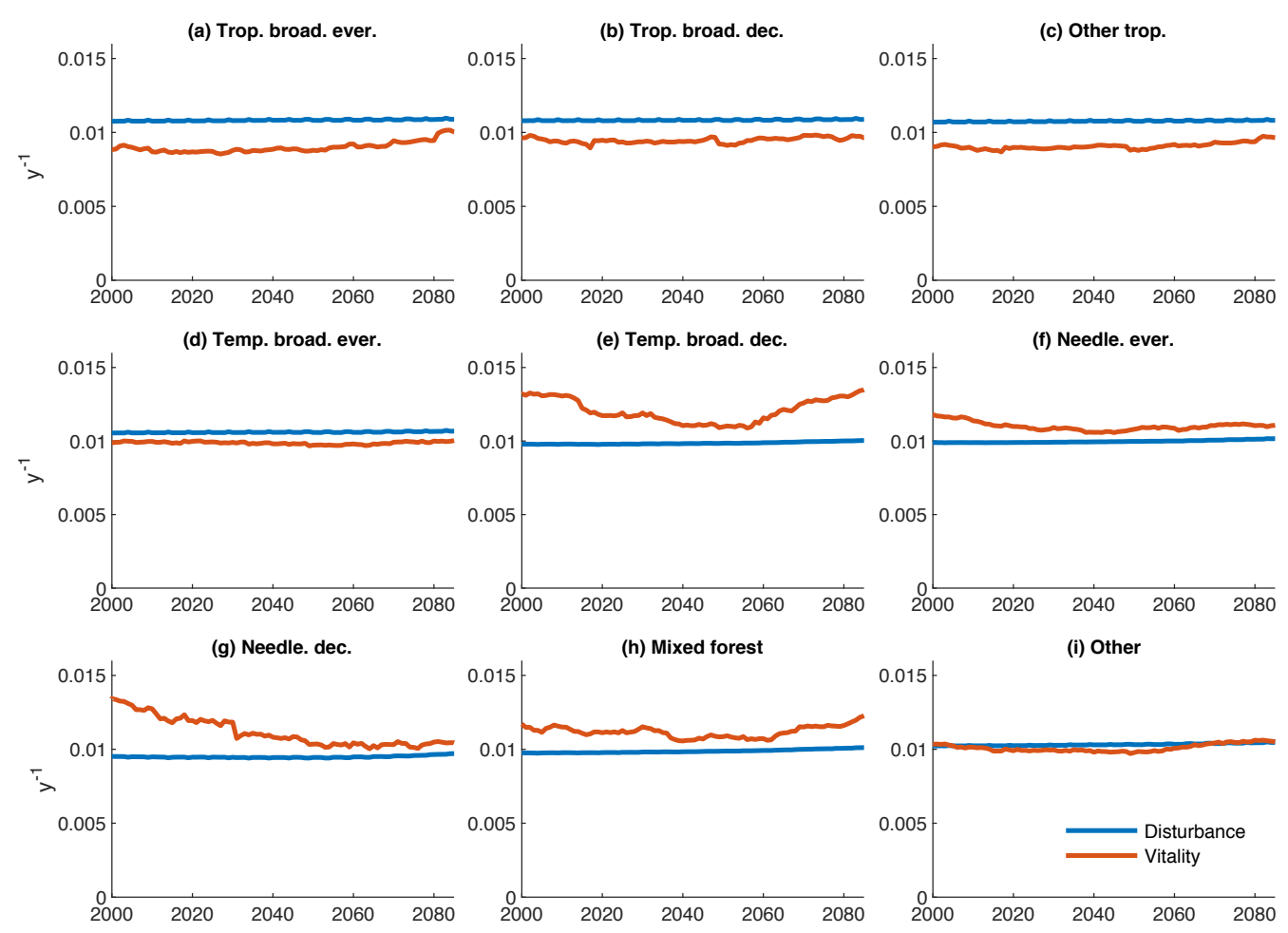

Figure S11. Mortality rate $\left(F_{\text {mort }} / C_{v e g}\right)$ for CABLE-POP split by conceptual process grouping (Table 3$)$ and observational forest type for 1985-2099 in the simulation forced by IPSL-CM5A-LR RCP 8.5 bias-corrected climate data. 31-year running means are plotted for clarity and thus only 2000-2085 is shown. Rates are calculated based on grid-cell total $\mathrm{C}_{\mathrm{veg}}$ and mortality fluxes. 

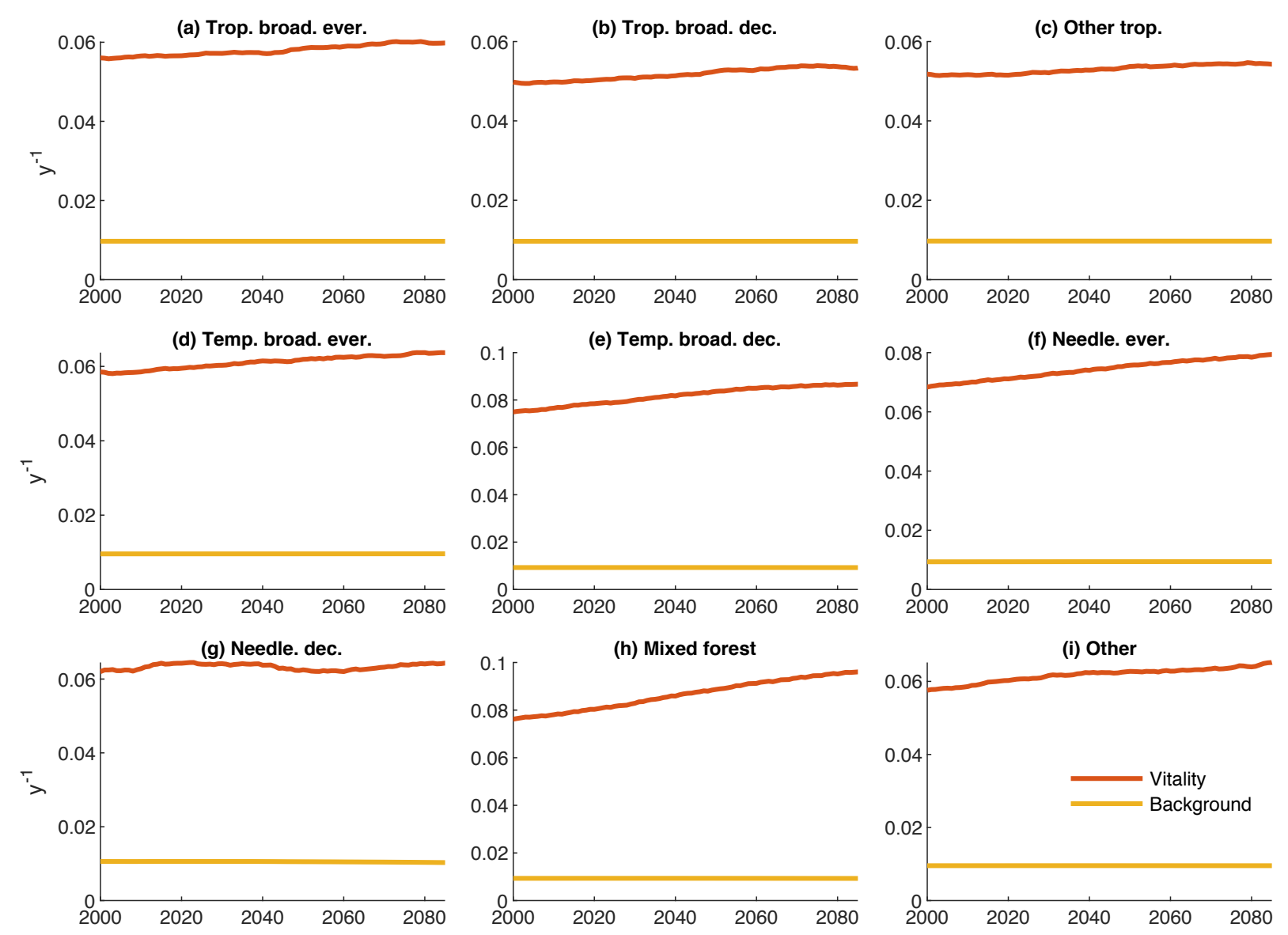

Figure S12. Mortality rate $\left(\mathrm{F}_{\mathrm{mor}} / \mathrm{C}_{\mathrm{veg}}\right)$ for JULES split by conceptual process grouping (Table 3) and observational forest type for 1985-2099 in the simulation forced by IPSL-CM5A-LR RCP 8.5 bias-corrected climate data. 31-year running means are plotted for clarity and thus only 2000-2085 is shown. Rates are calculated based on grid-cell total $\mathrm{C}_{\mathrm{veg}}$ and mortality fluxes. 

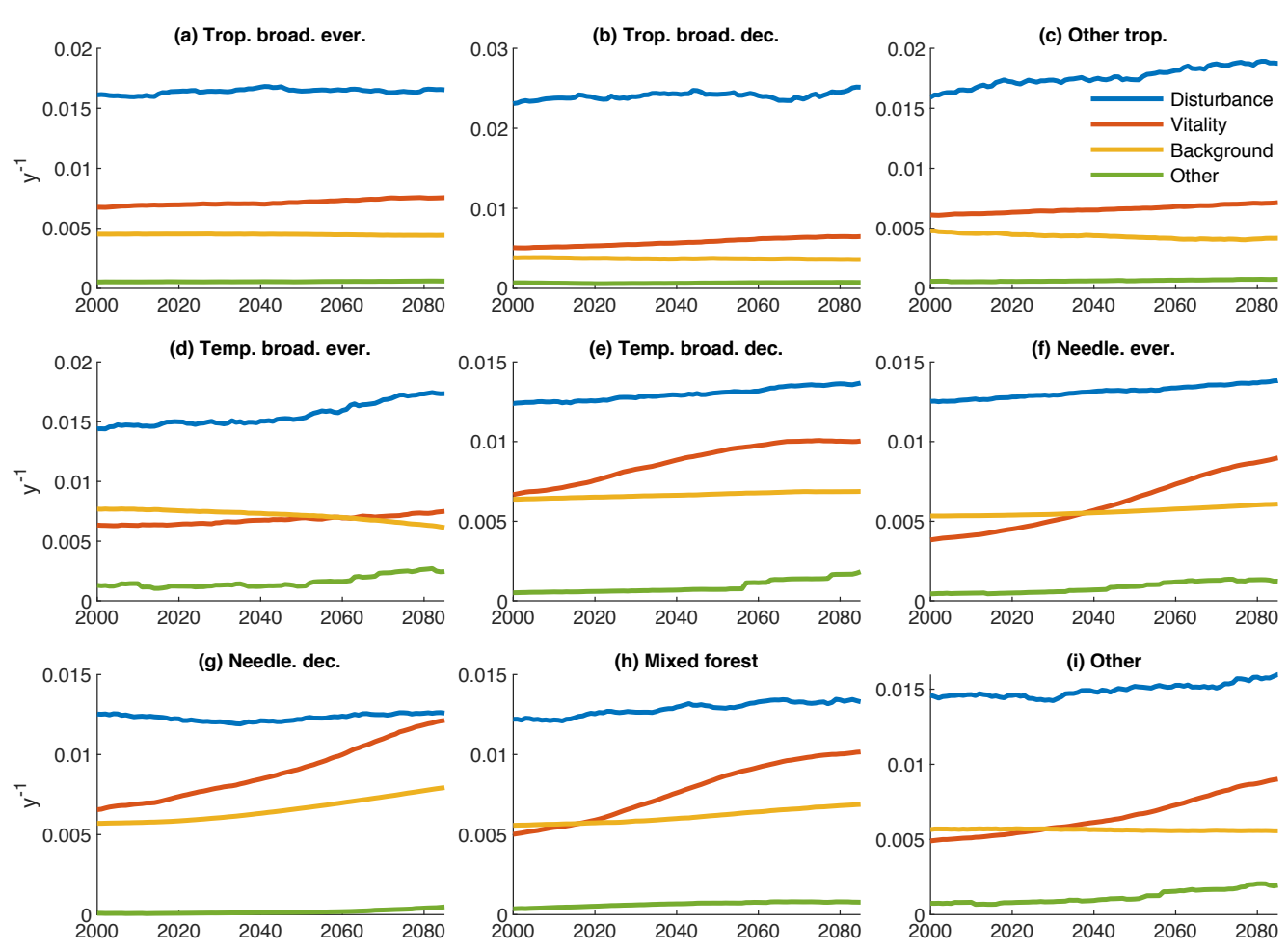

Figure S13. Mortality rate $\left(F_{\text {mort }} / C_{\text {veg }}\right)$ for LPJ-GUESS split by conceptual process grouping (Table 3$)$ and observational forest type for 1985-2099 in the simulation forced by IPSL-CM5A-LR RCP 8.5 bias-corrected climate data. 31-year running means are plotted for clarity and thus only 2000-2085 is shown. Rates are calculated based on grid-cell total $\mathrm{C}_{\mathrm{veg}}$ and mortality fluxes. 

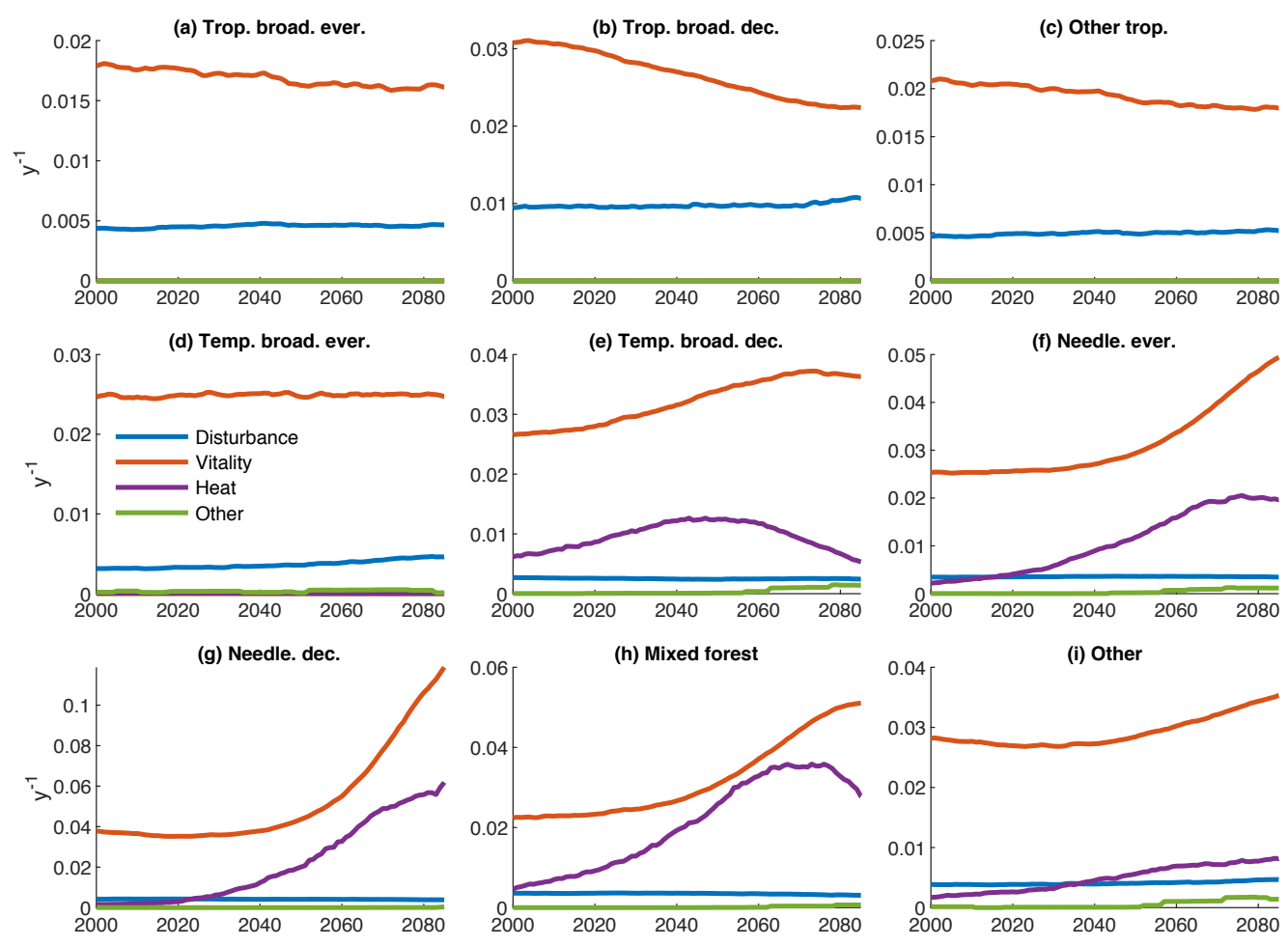

Figure S14. Mortality rate $\left(F_{\text {mort }} / C_{\text {veg }}\right)$ for $L P J m L$ split by conceptual process grouping (Table 3$)$ and observational forest type for 1985-2099 in the simulation forced by IPSL-CM5A-LR RCP 8.5 bias-corrected climate data. 31-year running means are plotted for clarity and thus only 2000-2085 is shown. Rates are calculated based on grid-cell total $C_{v e g}$ and mortality fluxes. 

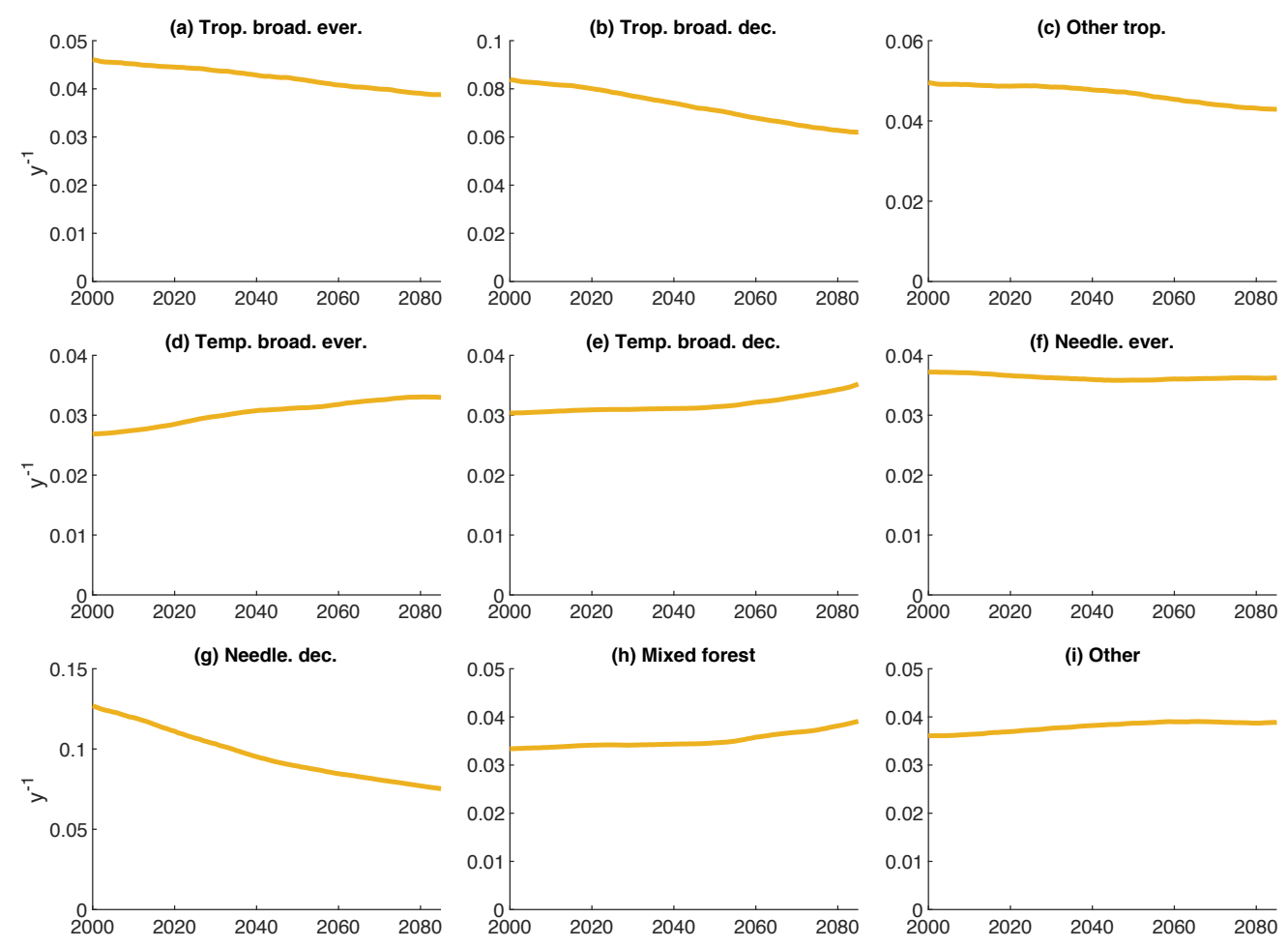

Figure S15. Mortality rate $\left(F_{\text {mort }} / C_{v e g}\right)$ for ORCHIDEE split by observational forest type for 1985-2099 in the simulation forced by IPSL-CM5A-LR RCP 8.5 bias-corrected climate data. No mechanism breakdown was available. 31-year running means are plotted for clarity and thus only 2000-2085 is shown. Rates are calculated based on grid-cell total $\mathbf{C}_{\mathrm{veg}}$ and mortality fluxes. 

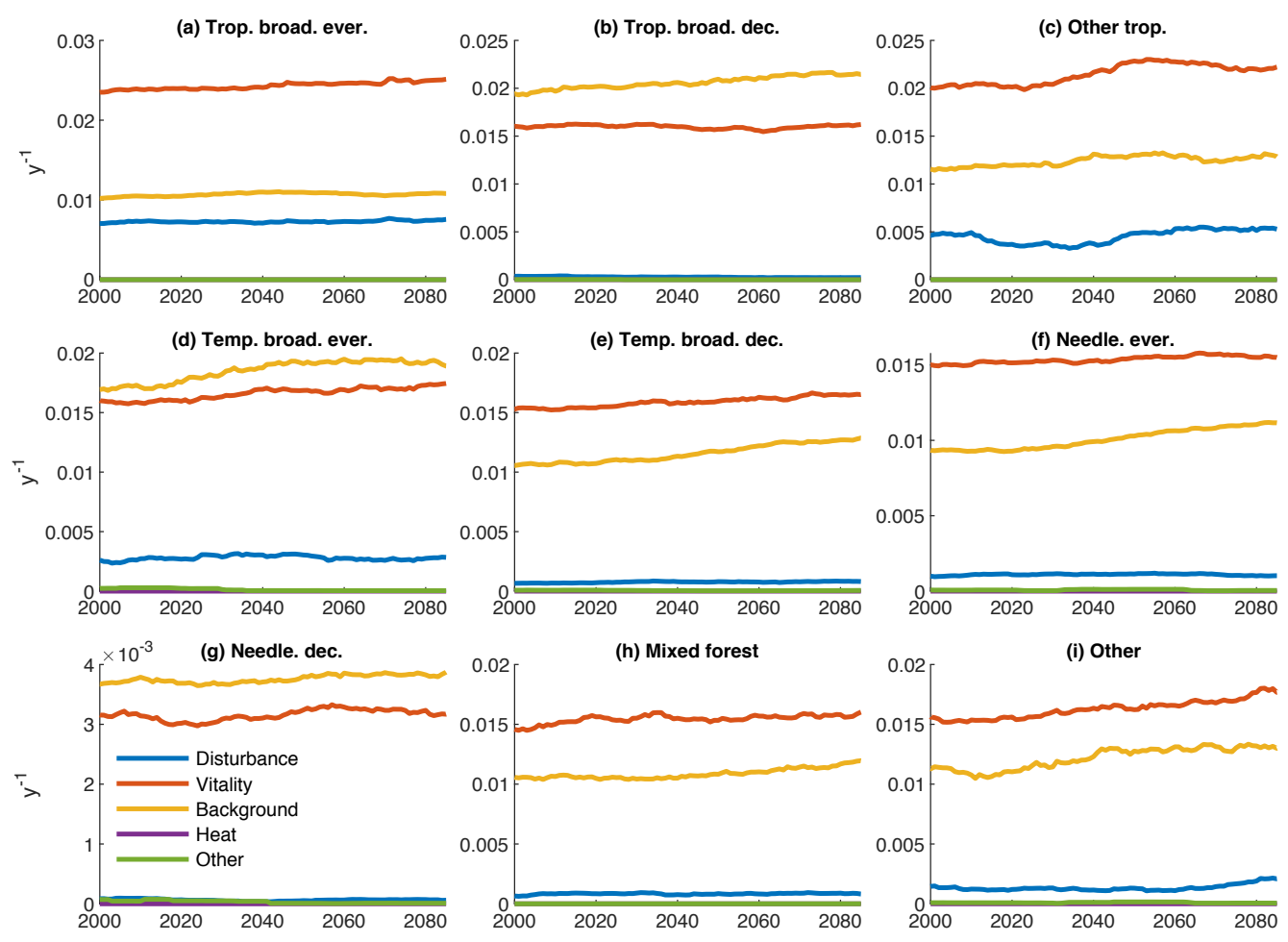

Figure S16. Mortality rate $\left(F_{\mathrm{mor}} / \mathrm{C}_{\mathrm{veg}}\right)$ for SEIB-DGVM split by conceptual process grouping (Table 3$)$ and observational forest type for 1985-2099 in the simulation forced by IPSL-CM5A-LR RCP 8.5 bias-corrected climate data. 31-year running means are plotted for clarity and thus only 2000-2085 is shown. Rates are calculated based on grid-cell total $\mathrm{C}_{\mathrm{veg}}$ and mortality fluxes. 


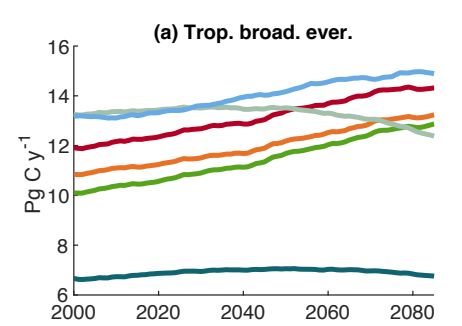

(d) Temp. broad. ever.
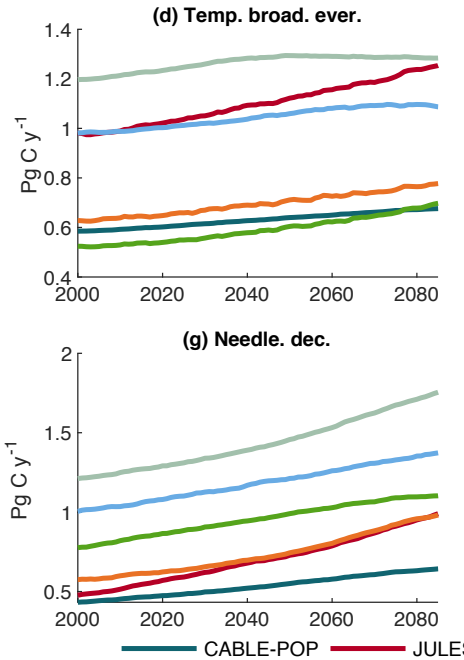

(b) Trop. broad. dec.

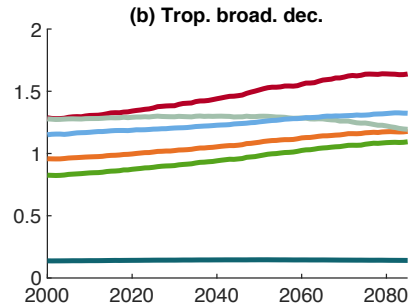

(e) Temp. broad. dec.

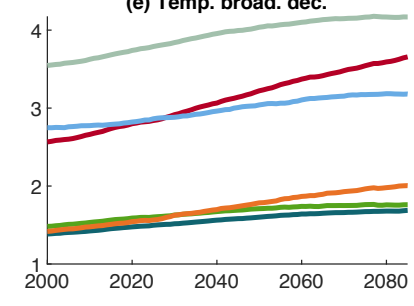

(h) Mixed forest

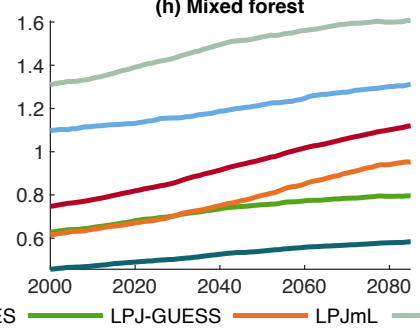

(c) Other trop.
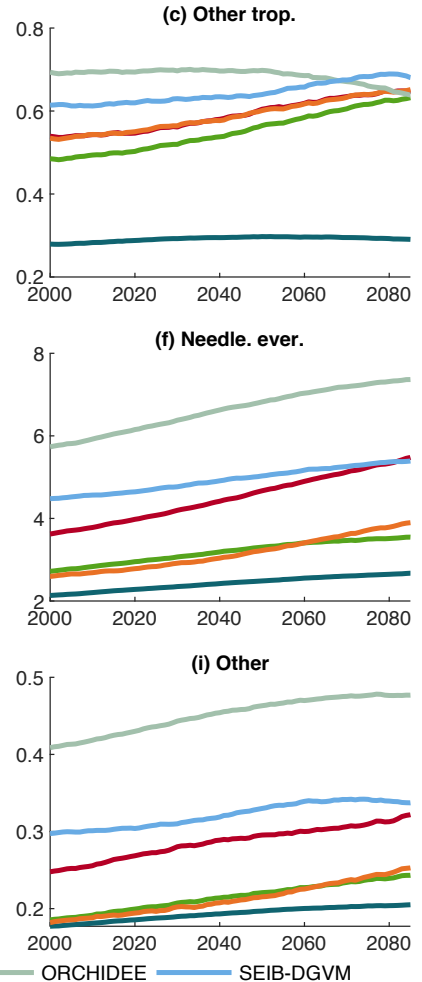

Figure S17. Change in NPP sums by observational forest type for 1985-2099 in the simulation forced by IPSL-CM5A-LR RCP 8.5 bias-corrected climate data. 31-year running means are plotted for clarity and thus only 2000-2085 is shown. 


\section{References}

Clark, D. B., Mercado, L. M., Sitch, S., Jones, C. D., Gedney, N., Best, M. J., Pryor, M., Rooney, G. G., Essery, R. L. H., Blyth, E., Boucher, O., Harding, R. J., Huntingford, C. and Cox, P. M.: The Joint UK Land Environment Simulator (JULES), model description - Part 2: Carbon fluxes and vegetation dynamics, Geosci. Model Dev., 4(3), 701-722, doi:10.5194/gmd-4-701-2011, 2011.

ESA: ESA CCI Land Cover dataset (v 2.0.7), [online] Available from: http://maps.elie.ucl.ac.be/CCI/viewer/ (Accessed 29 June 2017), 2017.

Hansen, M. C., Potapov, P. V, Moore, R., Hancher, M., Turubanova, S. A., Tyukavina, A., Thau, D., Stehman, S. V, Goetz, S. J., Loveland, T. R., Kommareddy, A., Egorov, A., Chini, L., Justice, C. O., and Townshend, J. R. G.: High-resolution global maps of 21 st-century forest cover change., Science, 342, 850-853, https://doi.org/10.1126/science.1244693, 2013.

Pugh, T. A. M., Arneth, A., Kautz, M., Poulter, B., and Smith, B.: Important role of forest disturbances in the global biomass turnover and carbon sinks, Nat. Geosci., 12, 730-735, https://doi.org/10.1038/s41561-019-0427-2, 2019 a.

Pugh, T. A. M., Lindeskog, M., Smith, B., Poulter, B., Arneth, A., Haverd, V., and Calle, L.: The role of forest regrowth in global carbon sink dynamics, Proc. Natl. Acad. Sci. U. S. A., 116(10), 4382-4387, https://doi.org/10.1073/pnas.1810512116, 2019b. 